REVIEW

\title{
Ocular coloboma: a reassessment in the age of molecular neuroscience
}

\author{
C Y Gregory-Evans, M J Williams, S Halford, K Gregory-Evans
}

J Med Genet 2004;41:881-891. doi: 10.1136/jmg.2004.025494

Congenital colobomata of the eye are important causes of childhood visual impairment and blindness. Ocular coloboma can be seen in isolation and in an impressive number of multisystem syndromes, where the eye phenotype is often seen in association with severe neurological or craniofacial anomalies or other systemic developmental defects. Several studies have shown that, in addition to inheritance, environmental influences may be causative factors. Through work to identify genes underlying inherited coloboma, significant inroads are being made into understanding the molecular events controlling closure of the optic fissure. In general, severity of disease can be linked to the temporal expression of the gene, but this is modified by factors such as tissue specificity of gene expression and genetic redundancy.

See end of article for authors' affiliations .....

Correspondence to: Dr Cheryl Y GregoryEvans, Department of Visual Neuroscience, 8th Floor Laboratory Block, St. Dunstan's Road, London W6 8RP, UK: c.gregory-evans@ imperial.ac.uk

Revised version received 20 July 2004

Accepted for publication 21 July 2004
C ongenital ocular colobomata (from the Greek koloboma, meaning "mutilated" or "curtailed") are caused by defects in embryogenesis. The incidence of coloboma depends upon the population studied, ranging from (per 10000 births) 0.5 in Spain, ${ }^{1} 1.4$ in France, ${ }^{2}$ and 2.6 in the $\mathrm{USA}^{3}$ to 7.5 in China. ${ }^{4}$ Coloboma has been reported in $0.6-1.9 \%$ of blind adults in Canada ${ }^{5}$ and $3.2-11.2 \%$ of blind children worldwide. ${ }^{6}$ Typically, colobomata are clefts caused by absent tissue in the inferonasal quadrant of the eye, but subtype, severity, and visual prognosis vary, depending on location and associated eye defects.

The underlying aetiology of the phenotype is the failure of the ectodermal optic vesicle fissure to close. ${ }^{7}$ This leads to colobomata affecting one or more areas of the eye including the cornea, iris, ciliary body, lens, retina, choroid, and optic nerve. Eyelid coloboma has also been described, but this is thought to arise from failure of the mesodermal folds to fuse at about 7-8 weeks of gestation. Information on the molecular mechanisms underlying coloboma pathogenesis is beginning to emerge based upon animal studies of coloboma and Mendelian genetic disorders, chromosomal abnormalities, toxic environmental agents such as drug usage, and dietary deficiency. The aim of this review is to highlight which genes are emerging as important in coloboma formation and how environment may also influence gene expression to cause coloboma.

\section{NORMAL EYE DEVELOPMENT}

The processes that occur during formation of the vertebrate eye are well documented and include (i) multiple inductive and morphogenetic events, (ii) proliferation and differentiation of cells into mature tissue, and (iii) establishment of neural networks connecting the retina to the higher neural centres such as the superior colliculus, the geniculate nucleus, and the occipital lobes. ${ }^{8-10}$ At around day 30 of gestation, the ventral surface of the optic vesicle and stalk invaginates leading to the formation of a double-layered optic cup. This invagination gives rise to the optic fissure, allowing blood vessels from the vascular mesoderm to enter the developing eye. Fusion of the edges of this fissure starts centrally at about 5 weeks and proceeds anteriorly towards the rim of the optic cup and posteriorly along the optic stalk, with completion by 7 weeks. ${ }^{11}$ Failure of part of the fetal fissure to close results in the clinical entity recognised as coloboma. The molecular mechanisms controlling these tissue events are largely unknown.

\section{CLINICAL FEATURES}

The typical, most frequently observed, ocular coloboma is seen in the inferonasal quadrant (fig 1A). ${ }^{10}$ Colobomata in other quadrants are atypical and the embryologic basis for these is unclear. Ocular colobomata are frequently seen in association with other developmental defects. In the eye, coloboma is often associated with microphthalmos and anophthalmia. ${ }^{12}$ Systemically, a large number of congenital defects are associated with coloboma (table 1), including craniofacial anomalies such as cleft lip, skeletal defects such as thumb hypoplasia, and genitourinary anomalies such as horseshoe kidney.

An interesting sub-classification has been proposed, based on corneal diameter and axial length. ${ }^{4}$ Colobomata are subdivided into those with cysts, those with microphthalmos ( small axial length), those with microcornea and normal axial length, and those with coloboma only. Such a classification can aid in determining visual prognosis, but does not take into account the effects on vision of chorioretinal and optic nerve colobomata, which can occur in the absence of cysts, microphthalmos, or microcornea. Since different types of

\footnotetext{
Abbreviations: $\mathrm{BMP}$, bone morphogenetic protein; CGN, Coloboma Gene Network; HPE, holoprosencephaly; MIA, multiple incomplete ascertainment; $R A$, retinoic acid; RPE, retinal pigment epithelium; SIA, single incomplete ascertainment; VAD, vitamin $A$ deficiency
} 
Table 1 Human diseases with eye coloboma and known genetic locus

\begin{tabular}{|c|c|c|c|c|c|c|}
\hline $\begin{array}{l}\text { OMIM } \\
\text { number }\end{array}$ & Disease & $\begin{array}{l}\text { Type of } \\
\text { coloboma }\end{array}$ & Inheritance & $\begin{array}{l}\text { Chromosome } \\
\text { location }\end{array}$ & Gene & Reference \\
\hline \multicolumn{7}{|c|}{ Genes or genetic loci linked to ocular coloboma } \\
\hline 274270 & DPD deficiency & I, C, M & $A R$ & $1 \mathrm{p} 22$ & DPD & Van Gennip et af ${ }^{13}$ \\
\hline 157170 & Holoprosencephaly 2 & $I, M$ & $A D$ & $2 \mathrm{p} 21$ & SIX3 & Wallis ef $a^{\beta 1}$ \\
\hline 235730 & Hirschsprung syndrome & 1 & $A D$ & $2 q 22$ & ZFHXIB & Gregory-Evans et $a l^{02}$, Hurst et $a f^{14}$ \\
\hline 601110 & CGDS type IV & i & $A R$ & $3 q 27$ & ALG3 & Korner et al ${ }^{115}$ \\
\hline 180500 & Reiger syndrome type 1 & $\mathrm{I}, \mathrm{M}$ & $A D$ & $4 \mathrm{p} 25$ & PITX2 & Ozkei et $a l^{16}$ \\
\hline 121050 & CCA syndrome & $\mathrm{R}, \mathrm{C}$ & $A D$ & $5 q 23-q 31$ & FBN2 & Bard et $a f^{17}$ \\
\hline 154500 & Treacher Collins & $\mathrm{I}, \mathrm{O}, \mathrm{L}$ & $A D$ & $5 q 32-q 33.1$ & TCOFI & $\begin{array}{l}\text { Treacher Collins Syndrome } \\
\text { Collaborative Group } \\
{ }^{118}\end{array}$ \\
\hline 600725 & Uveo-retinal coloboma & $\mathrm{I}, \mathrm{R}, \mathrm{C}, \mathrm{M}$ & $A D$ & $7 q 36$ & SHH & Schimmenti et a ${ }^{57}$ \\
\hline 109400 & Basal cell nevus/Gorlin & i & $A D /$ sporadic & $9 q 22.3$ & PTCH & Hahn et $a l^{68}$ \\
\hline 236670 & Walker-Warburg & $O, M$ & $A R$ & $9 q 34.1$ & POMT1 & Beltran-Valero de Bernabe et af ${ }^{19}$ \\
\hline 213300 & Joubert syndrome I & $R, C$ & $A R$ & $9 q 34.3$ & & Saar et $a l^{20}$ \\
\hline 180250 & RBP deficiency & l & $A D$ & $10 \mathrm{q} 24$ & RBP4 & Seeliger et $a^{\beta_{5}}$ \\
\hline 120330 & Renal-coloboma & $\mathrm{I}, \mathrm{R}, \mathrm{O}, \mathrm{M}$ & $A D$ & $10 q 24.3-25 q .1$ & PAX2 & Eccles and Schimmenti ${ }^{58}$ \\
\hline 120200 & Ocular coloboma & $\mathrm{R}, \mathrm{C}, \mathrm{O}$ & $A D$ & $11 p 13$ & PAX6 & Azuma et $a P^{4}$ \\
\hline 608091 & Joubert syndrome II & $\mathrm{R}, \mathrm{C}, \mathrm{O}$ & $A R$ & $11 \mathrm{p} 12-\mathrm{q} 13.3$ & & Keeler et $a f^{121}$ \\
\hline 163950 & Noonan syndrome & I, R, O & $A D$ & $12 q 24.1-q 24.3$ & PTPN1 1 & Carvalho et al ${ }^{122}$ \\
\hline 251600 & Microphthalmia & $\mathrm{R}, \mathrm{C}, \mathrm{M}$ & AR & $14 \mathrm{q} 24.3$ & CHX10 & Percin et $a F^{6}$ \\
\hline 600165 & Microphthalmia & I, R, M & $A D$ & $15 q^{12-q 15}$ & & Morrison et al ${ }^{109}$ \\
\hline 180849 & Rubinstein-Taybi & 1,0 & $\mathrm{AD} / \mathrm{del}$ & $16 p 13.3$ & CREBBP & Guion-Almeida and Richieri-Costa ${ }^{123}$ \\
\hline 177075 & Cataract/microcornea & i & $A D /$ trans & $16 q 22-q 23$ & MAF & Jamieson et $a F^{8}$ \\
\hline 249000 & Meckel-Gruber & $i$ & $A R$ & $17 q 22-q 23$ & & MacRae et $a l^{24}$ \\
\hline 166750 & Oculo-oto-dental & $\mathrm{I}, \mathrm{R}$ & $A D$ & $20 \mathrm{q} 13.1$ & & Vieira et $a l^{14}$ \\
\hline 305600 & Goltz syndrome & $\mathrm{I}, \mathrm{C}, \mathrm{O}$ & X-linked dom & $\mathrm{Xp} 22.31$ & & Gorski $^{125}$ \\
\hline 304050 & Aicardi syndrome & 0,1 & X-linked dom & Xp22 & & Ropres et $a l^{26}$ \\
\hline 300472 & Corpus callosum defect & 1,0 & $\mathrm{X}$-linked rec & $\mathrm{Xq13.1}$ & $|G B P|$ & Graham et al ${ }^{127}$ \\
\hline 309800 & Lenz syndrome & $\mathrm{I}, \mathrm{O}, \mathrm{C}, \mathrm{M}$ & X-linked rec & $\mathrm{Xq} 27-\mathrm{q} 28$ & $B C O R$ & $\mathrm{Ng}$ et $a l^{28}$ \\
\hline 304120 & Oto-palato-digital type2 & i & X-linked dom & Xq28 & FLNA & Robertson et $a l^{129}$, Stratton et al ${ }^{130}$ \\
\hline \multicolumn{7}{|c|}{ Chromosomal aberrations associated with coloboma } \\
\hline 120200 & Iris coloboma & I & - & 2p25-pter del & & Arias et $a l^{131}$ \\
\hline 243310 & Coloboma, ptosis, MR & i & - & $2 p 12-q 14$ inv & & Pallotta ${ }^{132}$ \\
\hline 218650 & Craniosynostosis & $\mathrm{R}, \mathrm{C}, \mathrm{O}$ & - & $2 q 24-2 q 31 \mathrm{del}$ & & Nixon et $a f^{133}$ \\
\hline 194190 & Wolf-Hirschhorn & 1 & - & 4 pl6.3 del & & Zollino et $a l^{134}$ \\
\hline 180500 & $4 \mathrm{q} 26$ deletion syndrome & I & - & $4 q 23-q 27$ del & & Motegi et $a l^{135}$ \\
\hline- & $7 q$ deletion syndrome & $\mathrm{R}, \mathrm{C}$ & - & $7 q 34-$ ter del & & Taysi et $a f^{136}$ \\
\hline 147791 & Jacobsen syndrome & I, R, C & - & 1 lq23-q25 del & & Pivnick et $a l^{137}$ \\
\hline 214800 & CHARGE association & $\mathrm{I}, \mathrm{R}, \mathrm{C}, \mathrm{O}$ & - & $8 q 21.1 \mathrm{del}$ & CHD7 & Vissers et af ${ }^{38}$ \\
\hline- & $16 q$ syndrome & $i$ & - & $16 q 23-16 q 24.2 \mathrm{del}$ & & Werner et $a l^{139}$ \\
\hline 115470 & Cat eye syndrome & $\mathrm{I}, \mathrm{C}, \mathrm{O}, \mathrm{L}$ & - & $22 q 11$ inv dup & & McTaggart et al ${ }^{140}$ \\
\hline 192430 & VCFS/Di George & $\mathrm{I}, \mathrm{R}, \mathrm{C}, \mathrm{M}$ & - & $22 q^{1} 1.22 \mathrm{del}$ & & Morrison et $a l^{141}$ \\
\hline 300337 & Hypomelanosis of to & I & Mosaicism & Xpl 1.2 trans & & Bartholomew et al ${ }^{12}$ \\
\hline
\end{tabular}

A, anophthalmia; $A D$, autosomal dominant; $A R$, autosomal recessive; C, choroid; del, deletions; dup, duplication; I, iris; inv, inversion; L, lid; $M$, microphthalmia; MR, mental retardation; O, optic nerve; R, retina; trans, translocation; VCFS, velo-cardiofacial syndrome. Table entries in bold type are eye-specific diseases without systemic defects.

colobomata can occur in individual families it is also unlikely that this classification identifies aetiologic subtypes.

\section{Iris coloboma}

A complete iris coloboma involves the pigment epithelium and stroma giving rise to the so-called "keyhole" pupil (fig 1B), which can be unilateral or bilateral. ${ }^{13} \mathrm{~A}$ partial coloboma involves only the pupillary margin making the pupil oval. Occasionally, the coloboma only affects the iris pigment epithelium and can be seen only on transillumination. ${ }^{14}$ Although isolated iris coloboma is observed, it is often associated with colobomata in other parts of the eye. Occasionally surgical repair is indicated either for cosmetic reasons or for photophobia. ${ }^{15-17}$

\section{Chorioretinal coloboma}

Colobomata affecting the posterior segment of the eye can be unilateral or bilateral. If the fetal fissure fails to close posteriorly, then a coloboma affecting the retinal pigment epithelium (RPE), neurosensory retina, or choroid may occur. The defect is essentially a bare sclera with the overlying RPE, retina, or choroid missing. In some cases although the retina is present, it is hypoplastic and gliotic. ${ }^{18}$ Typically occurring in the inferonasal quadrant, it may extend to include the optic nerve (fig 1C). Macular coloboma, which is not due to defects in optic fissure closure, should not be confused with chorioretinal coloboma. Usually, chorioretinal colobomata are asymptomatic despite significant upper visual field defects. It has been proposed that $8.1-43 \%$ of cases can be complicated by retinal detachment ${ }^{19-21}$ and surgical correction has variable success. ${ }^{22}{ }^{23}$ Rarely, chorioretinal colobomata give rise to subretinal neovascularisation, ${ }^{24}$ especially if involving the optic nerve head. ${ }^{25-27}$

\section{Optic nerve}

The severity of optic disc involvement varies from no involvement to an obviously enlarged optic cup to gross anomaly (fig 1D) unrecognisable as an optic nerve head. ${ }^{28}$ Visual deficit attributable to optic nerve head coloboma correlates with the severity of this anomaly. Two special cases are optic nerve pits ${ }^{29}$ (which can be associated with central serous retinopathy) and the morning glory disk anomaly ${ }^{30}$ (which can be associated with congenital forebrain anomalies). It is as yet uncertain whether these are types of coloboma, in the sense that they derive from failure of the optic fissure to close.

\section{AETIOLOGY}

\section{Coloboma and genetic abnormality}

An extraordinary number of conditions are associated with coloboma (74 entries in OMIM; see www.ncbi.nlm.nih. 


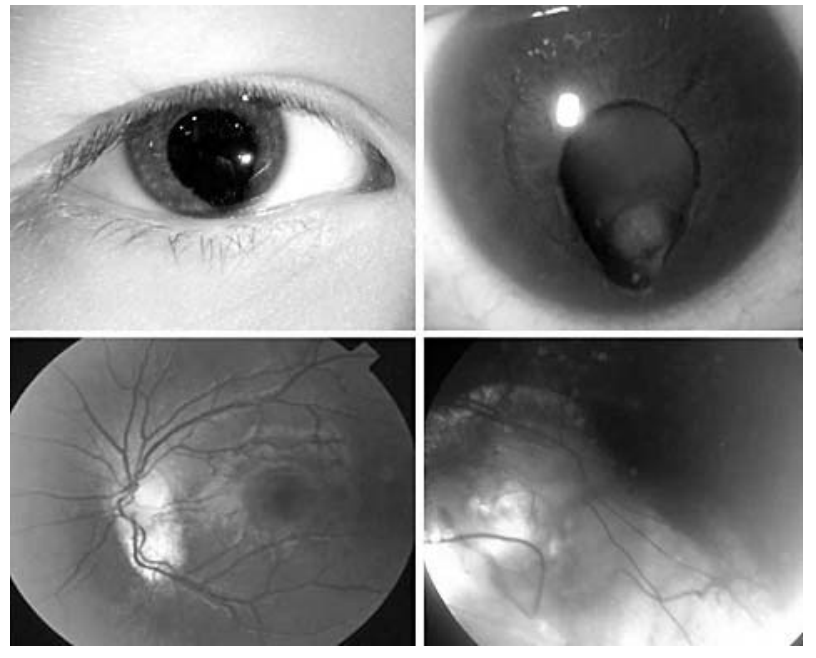

Figure 1 Clinical photographs of human ocular colobomata. (A) Typical iris coloboma; (B) iris coloboma with cataract; (C) small choroidal coloboma below optic nerve head; (D) large chorioretinal coloboma affecting retina and optic nerve head.

gov/entrez/query.fcgi?db = OMIM) either as Mendelian inherited traits or as chromosomal aberrations (tables 1 and 2). A key feature is that the majority of inherited coloboma cases, and especially those associated with chromosomal aberrations, are associated with systemic disease. To date, 27 genetic loci have been mapped to specific chromosomal regions and 21 of the genes have been identified (table 1). Eleven chromosomal aberrations have been documented and three of these overlap with known coloboma-associated genes (SHH, CHX10, MAF). Interestingly, three syndromes which include coloboma are due to chromosomal abnormality at 22q11: cat eye syndrome, velo-cardiofacial syndrome, and DiGeorge syndrome. This suggests there is a gene or genes important for optic fissure closure at this location. In phenotypes where there is no mapping information to date, 13 show autosomal dominant inheritance, 14 are autosomal recessive, three are thought to be X-linked, and in seven phenotypes the mode of inheritance has yet to be established (table 2). The coloboma phenotype is therefore genetically heterogeneous and is mostly associated with systemic disease.

\section{Environmental causes of coloboma}

A large proportion of sporadic, unilateral, coloboma cases are most likely due to non-genetic factors. Many non-Mendelian, multisystem malformation syndromes are associated with colobomata. Examples include CHARGE association where approximately $86 \%$ of patients have uveal or iris coloboma ${ }^{31}$ and nevus sebaceous of Jadassohn where some patients have iris and choroidal colobomata. ${ }^{32}$ The underlying mechanisms are not known for such syndromes, which constitute a significant proportion of coloboma cases.

There are many reports in the literature suggesting environmental associations with coloboma, ${ }^{33-37}$ but without appropriate case-controlled epidemiologic studies the data remain somewhat speculative. There are only a few clear associations which are described below, with appropriate caveats.

A number of studies in humans have led to the suggestion that the use of various drugs during pregnancy may be associated with ocular coloboma. For example, there seems reasonable evidence to support an effect of thalidomide and alcohol as reproducible studies have been documented. Children of expectant mothers treated with thalidomide manifested a number of eye malformations including coloboma (4\%) and microphthalmos $(7 \%) .{ }^{38}$ Up to $90 \%$ of children whose mothers have misused alcohol in pregnancy show ocular manifestations. A small proportion had isolated coloboma, but frequently these patients have microphthalmos, such that now this is now regarded as a specific sign of fetal alcohol syndrome. ${ }^{39}$ However, other associations with maternal use of drugs such as $\operatorname{LSD}^{40}$ and carbamazepine ${ }^{41}$ are less convincing, as they are case reports and have not been replicated in other patient populations..$^{42}$ Although numerous animal studies have been performed documenting the teratogenic effects of drugs, these studies are sometimes at doses much larger than used in humans and may not be relevant to human disease aetiology.

Several studies have suggested that maternal vitamin A deficiency (VAD) may be a cause of ocular coloboma in Asia. ${ }^{43}{ }^{44}$ Most recently, a study showed that $16 \%$ of pregnant women from South India who gave birth to a child affected with coloboma, had suffered night-blindness that reverted after birth. ${ }^{44}$ Evidence in support of a role for VAD is that $50 \%$ of pregnant women in parts of South India were found to have mild-to-moderate $\mathrm{VAD} .{ }^{44}$ However, due to the high frequency of consanguineous marriage in India, it has also been hypothesised that perhaps there is a genetic predisposition to the effects of VAD, leading to a higher prevalence of coloboma. ${ }^{45}$ In more westernised countries, however, it seems unlikely that dietary VAD would occur.

Other incidences of ocular coloboma in humans have been reported in association with maternal infections caused by cytomegalovirus; three cases) and toxoplasmosis (six reports), ${ }^{46}$ however, further studies are required before these associations are considered bona fide. In animal studies vitamin E deficiency, ${ }^{48}$ ionising radiation, ${ }^{49}{ }^{50}$ and hyperthermia $^{51}{ }^{52}$ have also been associated with coloboma. These associations at present require further rigorous study as there is no evidence that they cause an effect in humans.

\section{MOLECULAR BASIS OF COLOBOMA}

Whilst currently the molecular and cellular processes underlying optic fissure closure are poorly understood, this is changing rapidly with a great deal of genetic information being generated from family studies. An impressive number of very useful animal models have been described with an ocular coloboma phenotype (table 3 ). In the mouse, for example, nine genes have been identified, of which two are orthologous to human coloboma-associated disease genes (Pax2 and Pax6). Thus it is important to consider both human and mouse data in trying to dissect the molecular basis of coloboma.

Recent studies have demonstrated that the earliest developmental processes are controlled by a complex network of transcriptional factors, cell cycle regulators, and diffusible signalling molecules. ${ }^{53}$ These act in concert to form different ocular compartments, regulate cell proliferation, migration, and apoptosis, and specify cell identities. Mutations in some of these proteins or the genes they regulate leads to ocular coloboma. Evaluation of such genes associated with ocular coloboma in both humans and mice has led us to propose a CGN (Coloboma Gene Network) model (fig 2). Similar gene expression networks have proven useful in studies of fetal development $t^{54}$ and in understanding disease pathogenesis, for example in cancer. ${ }^{55}$ There are two key genes that underpin this network, Sonic hedgehog (SHH) and PAX6. Rare mutations in these genes are associated with coloboma phenotypes, however, both these genes act as transcriptional regulators of many other genes that are also associated with coloboma. It should also be noted that some of the coloboma phenotypes are rare and mutation-specific, but nonetheless provide insights into coloboma formation. 
Table 2 Familial coloboma without genetic localisation

\begin{tabular}{|c|c|c|c|c|}
\hline OMIM number & Disease & Type of coloboma & Inheritance pattern & Reference \\
\hline \multicolumn{5}{|c|}{ Autosomal dominant conditions } \\
\hline 184705 & Steinfeld syndrome & $\mathrm{I}, \mathrm{R}$ & $A D$ & Nothen et $a l^{143}$ \\
\hline 602499 & Macrophthalmia & I, R, O & $A D$ & Toker et al ${ }^{144}$ \\
\hline 120433 & $\begin{array}{l}\text { Coloboma/cleft lip and } \\
\text { palate/MR/deafness }\end{array}$ & $\mathrm{I}, \mathrm{R}, \mathrm{C}, \mathrm{O}, \mathrm{M}$ & $A D$ & Ravine et $a l^{145}$ \\
\hline 102490 & Acro-reno-ocular syndrome & I, C, O & $A D$ & Aalfs et al ${ }^{16}$ \\
\hline 113620 & Branchio-oculo-facial & $\mathrm{I}, \mathrm{R}, \mathrm{O}, \mathrm{M}$ & $A D$ & Richardson et al ${ }^{47}$ \\
\hline 280000 & Chime syndrome & $\mathrm{R}$ & $A D$ & Shashi ef $a l^{48}$ \\
\hline 142500 & Heterochromia iridis & I & $A D$ & Morrison et al ${ }^{199}$ \\
\hline 147920 & Kabuki syndrome & $\mathrm{I}, \mathrm{R}, \mathrm{C}, \mathrm{O}$ & $A D$ & Ming et $a l^{150}$ \\
\hline 157980 & MOMO syndrome & $\mathrm{R}$ & $A D$ & Moretti-Ferreira et $a l^{51}$ \\
\hline 155145 & Pai syndrome & I & $A D$ & Rudnik-Schoneborn and Zerres ${ }^{152}$ \\
\hline 601707 & Curry-Jones syndrome & $\mathrm{I}, \mathrm{M}$ & $A D$ & Temple et $a l^{153}$ \\
\hline 201350 & Biemond syndrome type 2 & I, R, M & $A D, A R$ & Verloes et al ${ }^{154}$ \\
\hline \multicolumn{5}{|c|}{ Autosomal recessive conditions } \\
\hline 601706 & Yemenite deaf-blind (severe) & $\mathrm{I}, \mathrm{C}$ & AR & Bondurand et $a l^{155}$ \\
\hline 223370 & Dubowitz syndrome & $I, M$ & AR & Tsukahara and Opitz ${ }^{156}$ \\
\hline 218340 & Temtamy syndrome & I, R, C & $A R$ & Temtamy et al ${ }^{157}$ \\
\hline 216820 & Ocular coloboma & $\mathrm{R}, \mathrm{C}$ & AR & Pagon et al ${ }^{158}$ \\
\hline 229400 & Frontofacionasal dysostosis & $\mathrm{I}, \mathrm{L}$ & $A R$ & Gollop et al ${ }^{159}$ \\
\hline 220210 & Ritscher-Schinzel syndrome & $\mathrm{I}, \mathrm{R}$ & $A R$ & Leonardi et al ${ }^{160}$ \\
\hline 251505 & Microphthalmia & $\mathrm{R}, \mathrm{C}$ & AR & Porges et $a l^{61}$ \\
\hline 222448 & Donnai-Barrow syndrome & 1 & $A R$ & Avunduk et $a l^{162}$ \\
\hline 216360 & $\mathrm{COACH}$ syndrome & I, C, O & $A R$ & Verloes and Lambotte ${ }^{163}$ \\
\hline 274205 & Hypoplastic thumb, coloboma & C & $A R$ & Ward et $a f^{164}$ \\
\hline 601427 & Anterior chamber cleavage & 1 & $A R$ & Jung et $a l^{165}$ \\
\hline 244300 & Kapur-Toriello & 1 & $A R$ & Kapur and Toriello ${ }^{166}$ \\
\hline 215105 & Chondrodysplasia punctata & $\mathrm{R}$ & $A R$ & Toriello et al ${ }^{167}$ \\
\hline \multicolumn{5}{|c|}{ X-linked conditions } \\
\hline 258865 & Oral-facial-digital type VIII & $\mathrm{R}, \mathrm{C}$ & X-linked & Gurrieri et $a f^{168}$ \\
\hline 302380 & Catel-Manzke syndrome & 1 & X-linked & Wilson et al ${ }^{69}$ \\
\hline 600122 & Verloes syndrome & C & Probably X-linked & de Die-Smulders et $a l^{170}$ \\
\hline \multicolumn{5}{|c|}{ Inheritance pattern not yet determined } \\
\hline 234100 & Hallermann-Streiff syndrome & $\mathrm{I}, \mathrm{C}, \mathrm{O}, \mathrm{M}$ & Sporadic & Cohen $^{171}$ \\
\hline 163200 & Nevus sebaceous of Jadassohn & I, C, L & Sporadic & Baker et $a^{\beta 2}$ \\
\hline 136760 & Frontonasal dysplasia & $\mathrm{R}, \mathrm{C}$ & Sporadic & Temple et al ${ }^{72}$ \\
\hline 165630 & Organoid nevus phakomatosis & $\mathrm{R}, \mathrm{C}$ & Mosaicism & Neumann et $a l^{173}$ \\
\hline 601359 & Sebaceous nevus syndrome & 1 & Mosaicism & Dodge and Dobyns ${ }^{174}$ \\
\hline 107550 & Aortic arch anomalies & $\mathrm{R}$ & Twins & Levin ef $a l^{175}$ \\
\hline- & Familial iris coloboma & I & Pre-mutation & Barros-Nunez et al ${ }^{176}$ \\
\hline
\end{tabular}

\section{$\mathrm{SHH} / \mathrm{Sh}$ regulated genes and coloboma}

Sonic hedgehog is a secreted protein that regulates embryonic morphogenesis through an intracellular signalling network. ${ }^{56}$ It is expressed in the floorplate of the neural tube and when disrupted in mouse leads to cyclopia and neural tube defects. ${ }^{57}$ The $S h^{-1-}$ mouse is therefore lethal due to severe neurological maldevelopment. Interestingly, the $S h^{+/-}$ mouse is indistinguishable from wild-type, yet in humans SHH heterozygous mutations lead to holoprosencephaly (HPE3). The HPE3 eye phenotype ranges from cyclopia, anophthalmia, and microphthalmia to coloboma. Intriguingly though, a 12 bp deletion in SHH has been shown to

Table 3 Animal models with ocular coloboma

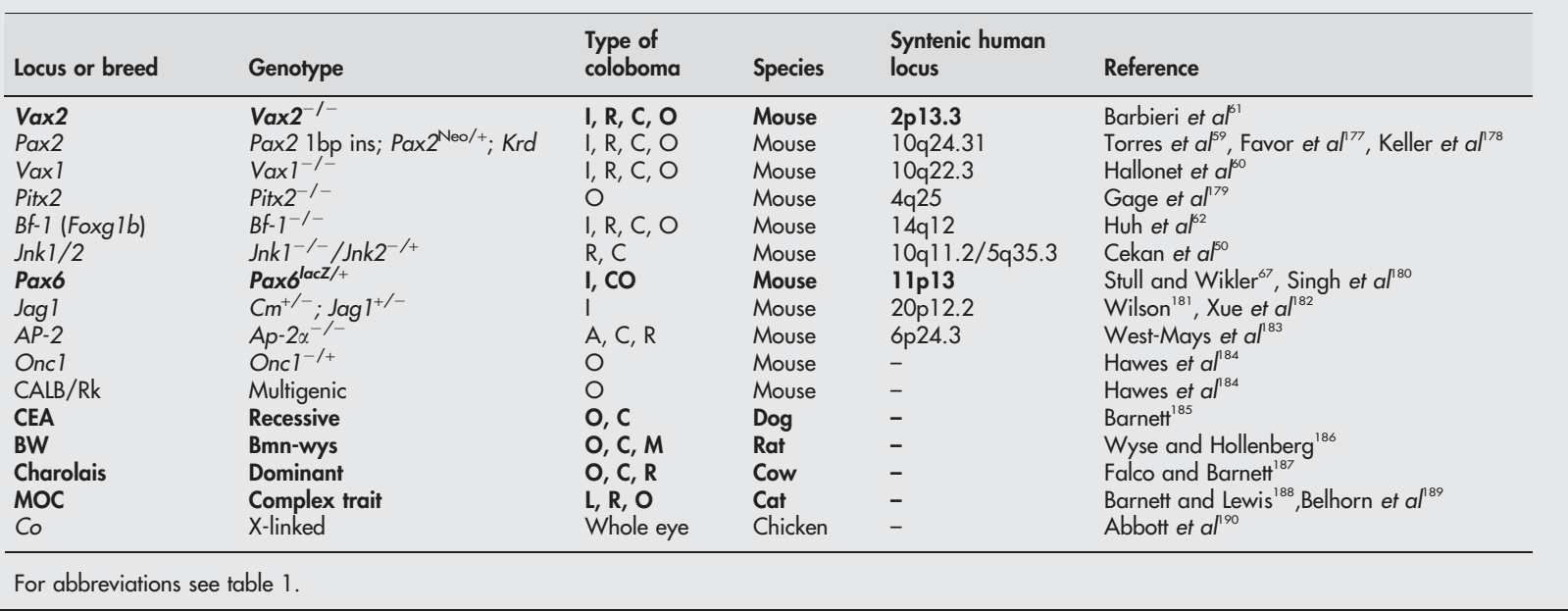




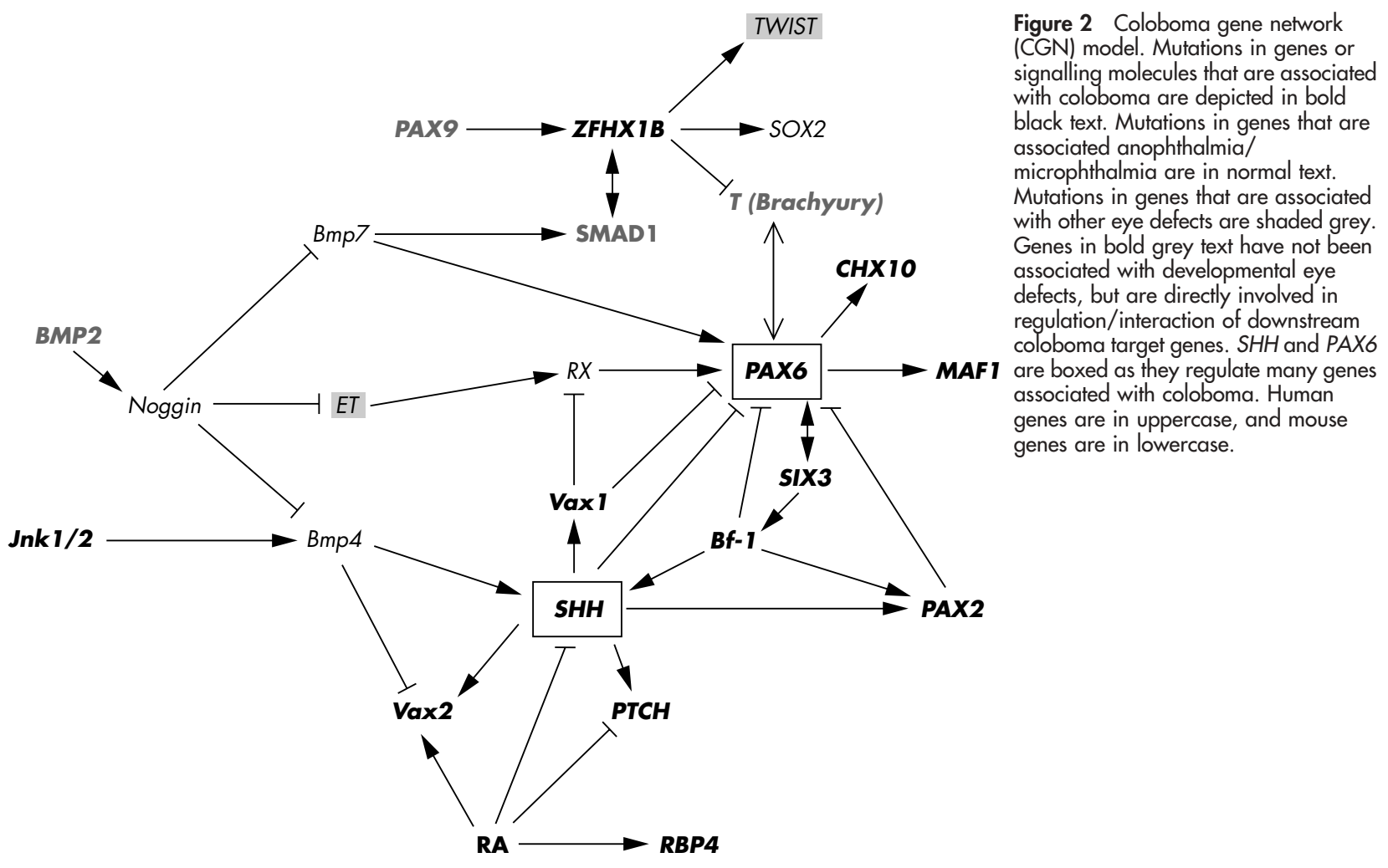

cause isolated colobomatous microphthalmia affecting the iris, retina, and choroid without holoprosencephaly, highlighting the genotype-phenotype specificity. ${ }^{57}$

Sonic hedgehog regulates a number of genes which have also been directly associated with ocular coloboma (fig 2). Heterozygous mutations in PAX2, for instance, cause renalcoloboma syndrome, resulting in coloboma of the uveal tract and in some cases microphthalmia. ${ }^{58}$ In homozygous Pax2 null mutant mice, the optic fissure fails to close, resulting in bilateral coloboma at birth. ${ }^{59}$ Pax 2 is expressed early in the ventral half of the optic vesicle and in the lips of the closing optic fissure, extending ventrally to the optic stalk. Interestingly, it has been suggested that in the Pax2 mutant mice there is no contact-dependent dissolution of the basal lamina of the neuroepithelium at the fissure edges, and therefore closure is inhibited. Thus, these studies suggested that Pax2 has a direct role in optic fissure closure.

Shh also regulates two closely-related homeobox genes, Vaxl and Vax2. In $\operatorname{Vaxl}^{-1-}$ mutants there is ocular coloboma, optic nerve agenesis, and abnormal projections of the retinal ganglions cells to the brain consistent with the normal expression of $\operatorname{Vaxl}$ in the optic stalk. ${ }^{60}$ In these mice, Vaxl was also shown to negatively regulate both Pax6 and $R x$ gene expression, but had no effect on Pax2 expression. Vax $2^{-1-}$ knockout mice exhibit coloboma, consistent with the exclusive expression pattern of Vax2 in the ventral part of the developing eye. ${ }^{61}$ This is similar to Pax2 mutants where the basal lamina persists preventing optic fissure closure. Neither Pax2 nor Tbx5 expression patterns were altered by the absence of Vax2, suggesting that the coloboma was a direct consequence of Vax2 inactivation. The human VAX1 or VAX2 genes are, therefore, good candidate genes for ocular coloboma, however, no mutation screens have been reported to date, perhaps because these genes have only recently been identified.

$B f-1($ Foxglb $)$ is a winged-helix transcription factor and is normally expressed early at the time of optic vesicle evagination and later in the optic cup and stalk. Targeted disruption of the gene in mice leads to absence of the optic stalk and an expanded retina ${ }^{62}$ in addition to brain defects. The eyes are not spherical in shape and there is a large ventral coloboma. In the absence of $B f-1$ there is an increase in Pax6, a loss of Pax2, and a localised deficit of Shh expression around the base of the optic vesicle. To date, no mutation screens have been reported in human eye disease.

The signalling molecule retinoic acid (RA), a derivative of vitamin $\mathrm{A}$, has been shown to regulate eye development. ${ }^{63}$ There is evidence to suggest that in some populations dietary deficiency of vitamin A and its derivatives seems to be linked to ocular coloboma both in humans ${ }^{44}$ and mammals. ${ }^{64}$ RA upregulates the retinoid binding protein gene (RBP4) and a missense mutation in $R B P 4$ results in iris coloboma and retinal dystrophy in a sib-pair. ${ }^{65}$ Patched-1 (Ptch) and Shh expression are negatively regulated by RA. ${ }^{66}$ Absence of RA results in coloboma ${ }^{67}$ and mutation of human $P T C H$ leads to iris and lid colobomata in association with multiple basal cell carcinomas, craniofacial defects, and skeletal abnormalities. ${ }^{68}$ Furthermore, in Xenopus eye development RA has been shown to upregulate Vax2, again implicated in coloboma. ${ }^{69}$ These studies would support a role for RA in the signalling pathway controlling closure of the optic fissure.

The c-Jun $\mathrm{NH}_{2}$-terminal kinase (Jnk) subfamily of protein kinases are stimulated by cellular stress and pro-inflammatory cytokines. Targeted disruption of either Jnkl or Jnk2 has no effect on the eye, and it has been assumed that each can compensate for the other. When these knockout mice have been backcrossed to each other, however, a number of interesting effects are seen. Mice which lacked both Jnkl and Jnk2 (Jnk2 $\left.2^{-1-} J n k 1^{-1-}\right)$ died during gestation with neural tube and brain defects. ${ }^{70}$ Mice which lacked $J n k 2$, but had a

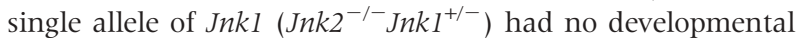
phenotype, whereas the absence of Jnkl and the presence of only one copy of $J n k 2\left(J n k 1^{-/-} J n k 2^{+/-}\right)$resulted in retinal coloboma, small lenses, and other developmental defects. ${ }^{71}$ 
Gene expression and complementation studies in the Jnkl/2 embryos revealed the signalling pathway of Jnkl/ $2>$ Bmp $4>\operatorname{Sh} h>$ Pax $2>$ coloboma, the first definitive coloboma pathway to be dissected.

\section{PAX6/Pax6 regulated genes and coloboma}

The $P A X 6$ gene, expressed in the developing central nervous system including the eye, has been shown to be vital to eye development and to be influential at the earliest stages of ocular morphogenesis (master control gene). It was first identified as the candidate gene for aniridia, ${ }^{72}$ however, numerous mutations in the gene have been causally associated with an impressive range of ocular phenotypes, ${ }^{73}$ all detailed in the Human PAX6 Allelic Variant Database (http://pax6.hgu.mrc.ac.uk/Tables/tables.htm). Of particular interest here, rare missense mutations in PAX6 have been shown to cause optic nerve and chorioretinal coloboma in $\operatorname{man}^{74}$ and mouse, ${ }^{75}$ whereas the more severe aniridia phenotype is commonly associated with nonsense/frameshift mutations, highlighting a genotype-phenotype correlation for PAX6.

There are a number of genes downstream of PAX6 that have also been directly associated with eye coloboma. Mutation of the CHX10 gene for example, leads to iris and chorioretinal colobomata with microphthalmia/anophthalmia. ${ }^{76}$ Although the whole eye is affected by loss of Chx10 function, the primary genetic defect is specific to the retina. ${ }^{77}$ How this is related to failure of the optic fissure to close is not yet known.

Mutation of the $M A F 1$ gene leads to cataract, microcornea, microphthalmia, and bilateral iris coloboma. ${ }^{78}$ The gene is expressed during lens differentiation and regulates crystallin gene expression. However, MAFl may play a bigger role in anterior segment formation since an iris coloboma has been associated with mutant MAFI in one study. Cell culture studies have implicated Pax6 in the regulation of $M a f^{79}$ and Maf and Sox2 cooperatively regulate the expression of deltacrystallin during chick lens development. ${ }^{80}$ Whether Maf and Sox2 cooperatively regulate optic fissure closure has not been examined to date.

Mutation of the SIX3 gene causes holoprosencephaly (HPE2; single central incisor and microcephaly, with or without associated brain malformations) with associated ocular defects such as cyclopia, iris coloboma, microphthalmia, or hypertelorism. ${ }^{81}$ In the mouse, Six3 is first expressed in the optic vesicles and stalks at E9.5, and then later is limited to the retina and lens. ${ }^{82}$ Studies of Six 3 knockout mice show abnormal forebrain development and complete absence of eyes, indicating its central role in eye development. ${ }^{82}$ In zebrafish retina Six3 is directly regulated by $\mathrm{Pax}^{8},{ }^{83}$ however, Six3 can also up-regulate Pax6 during eye field specification early in development. ${ }^{84}$ The ability of Pax6 and Six3 to induce each other's expression is consistent with their overlapping expression patterns in the developing eye. ${ }^{82} 84$ These data suggest that mutation of SIX3 has a role in coloboma formation.

\section{Anophthalmia/microphthalmia genes}

A number of genes ( $R X, B m p 7, B m p 4, N o g, S O X 2)$, which have been associated with anophthalmia/microphthalmia, interact with or regulate some of the genes associated with a coloboma phenotype and have been included in the CGN network (fig 2). Pax6 is directly regulated by $S_{h h}{ }^{85} R x^{86}$ and $B m p 7^{87}{ }^{88}$ during different aspects of murine eye morphogenesis such as optic stalk and vesicle formation. Temporal expression studies in Xenopus have suggested that there is a specific network of transcription factors during eye field development. ${ }^{84}$ During early eye specification in Xenopus, ET induces sequentially $R x$, Pax6, and then Six, and ET itself is strongly repressed by Nog. These data in vivo support the recent finding that mutations in human $R X(R A X)$ cause anophthalmia, without systemic defects. ${ }^{89}$

During eye development $B m p 7$ is expressed in the neuroepithelium of the optic vesicle at day Ell.5 and is limited to the presumptive neural retina and developing lens placode. From E12.5 to E13.5, there is expression in the neural retina, lens, and developing cornea. ${ }^{90} 91 \mathrm{Bmp} 4$ is expressed in the optic vesicle and in the trabecular meshwork and optic nerve head cells of mature tissue. ${ }^{92}$ Targeted deletion of the mouse Bmp7 gene results in anophthalmia (also kidney and skeletal defects), ${ }^{93}$ whereas heterozygous Bmp4 mice exhibit microphthalmia (also kidney, skeletal, and craniofacial defects). ${ }^{94}$ These data suggest that the bone morphogenetic protein (BMP) genes have a critical role in eye development. No mutations in the human BMP4 or BMP7 genes have yet been reported in association with anophthalmia/microphthalmia. However, this may be due to redundancy because there are overlapping regions of expression in the developing eye of Bmp4 and Bmp7. ${ }^{95}$

A number of studies show that Nog is able to repress the transcription of Bmp7 and Bmp4..$^{90}{ }^{96}$ Over-expression of $\mathrm{Nog}$ in chick embryos at optic vesicle stages of development results in microphthalmia with concomitant disruption of the developing neural retina, RPE, and lens. At optic cup stages, however, Nog overexpression caused colobomata and ectopic expression of optic stalk markers in the region of the ventral retina and RPE. Transgenic over-expression of Nog in mice prevents the eyelids from opening. ${ }^{97}$ These antagonist effects of Nog prevent the appropriate expression of BMPs downstream, and thus have a coloboma/microphthalmia effect similar to targeted deletion of BMPs themselves. In humans six missense mutations in $N O G$ cause proximal symphalangism without eye defects, consistent with the absence of eye defects in the Noggin null mouse. ${ }^{98}$ No mutations have yet been described which have a gain of function that would be predicted to have a microphthalmia/ coloboma phenotype.

Another role for $B m p 7$ is in up-regulation of SMAD1.99 SMADI interacts with $Z F H X 1 B$, a zinc finger transcription factor that is expressed in craniofacial mesenchyme and migrating neural crest cells. ${ }^{100}$ Targeted deletion of Zfhxlb prevents closure of the neural tube and a heterozygous mutation in the human $Z F H X I B$ gene results in Hirschsprung syndrome ${ }^{101}$ with bilateral iris and retinal colobomata. ${ }^{102}$ In Zfhxlb knockout mice Sox2 is absent and Twist is markedly suppressed; in man SOX2 mutations lead to anophthalmia ${ }^{103}$ and TWIST mutations lead to eyelid abnormalities in SaethreChotzen syndrome. ${ }^{104}$ Unfortunately, there was no investigation of the eyes of these Zfhxlb null mice. However, ZFHXIB is expressed in the eye from 7-9 weeks of human development ${ }^{105}$ and overexpression of the Xenopus gene results in defective eye development. ${ }^{106}$ Furthermore, Zfhxlb also negatively regulates the mouse $T$ (Brachyury) gene. ${ }^{107}$ Overexpression of Pax6 in zebrafish embryos results in greatly reduced eye and forebrain development, whereas overexpression of the zebrafish $T$ gene has no effect on the eye, consistent with the absence of any reported disease-causing mutations of $T$ in humans. However, simultaneous injection of Pax6 and $Z f-T$ resulted in embryos lacking eyes ${ }^{108}$ suggesting that both of these genes are required during eye development.

\section{GENETIC COUNSELLING}

An extensive review of genetic counselling in coloboma cases is beyond the remit of this review, however, a guide for managing familial cases, isolated coloboma, or cases with systemic features is described below. If a familial form of coloboma or a specific syndrome of which coloboma is a part is identified, then counselling follows a conventional method 
based on the applicable Mendelian inheritance (autosomal dominant, recessive, or X-linked). More commonly, and more difficult, are simplex cases where a coloboma patient has no family history.

If a patient has an isolated coloboma then consideration of reported recurrence risks is useful; however, these studies are limited. A study in Scotland, over a 16 year period, reported sibling recurrence risks of $8.1 \%$ (single incomplete ascertainment, SIA) and $13.3 \%$ (multiple incomplete ascertainment, MIA) ${ }^{109}$ When bilateral cases were analysed separately, the risk to siblings seemed to be higher $(33 \%)$ than with unilateral cases. However, when the parents of these simplex cases with bilateral coloboma were more critically examined, many cases of occult (often retinal) coloboma were seen, suggesting dominant inheritance. Where both parents were found to be normal, the bilateral recurrence risk dropped to $2.9 \%$ (SIA) and 4.3\% (MIA). For unilateral coloboma probands no cases of occult disease in parents were seen and the recurrence risk was estimated to be $4.9 \%$ (SIA) and $7.9 \%$ (MIA). Surprisingly, this suggests that in cases where parents are definitely unaffected, the risk to other siblings is slightly greater in unilateral than bilateral cases. This emphasises the need to thoroughly examine parents prior to counselling, especially in bilateral cases, to ascertain if there could be a dominant pattern of inheritance.

In a French study, over a 15 year period, congenital eye malformations were considered as a whole group (including microphthalmia, anophthalmia, cataract, and coloboma) and the recurrence risk for first degree relatives of probands was estimated to be $8.9 \% .^{2}$ However, in $54 \%$ of the cases, there were systemic malformations and so the reported recurrence risk is not specific to isolated coloboma, but does highlight the frequent association of coloboma with other phenotypes. The Scottish study also reported that many coloboma cases with systemic features ( 31 of 40 ) could not be assigned to a specific syndrome, making assessment of risk difficult. In fact, 11 of the 12 reported cases of coloboma with chromosomal aberrations (table 1) have been in cases associated with multiple systemic defects. Therefore, karyotyping might be of particular value in the genetic counselling of this subgroup, but is unlikely to be of value in isolated coloboma. Another factor relevant here is that clinicians need to be aware that ocular coloboma can be the presenting feature of a great number of systemic developmental disorders, and they should therefore investigate these cases accordingly.

Further refinement in genetic counselling will be based on new information on genes causing coloboma; the potential use of genes in diagnosis and screening is an emerging factor in clinical management. When specific syndromes such as renal-coloboma syndrome are considered, the PAX2 gene should be screened. Similarly, when holoprosencephaly is seen with coloboma, the SIX3 and SHH genes could be screened. For isolated coloboma cases, human and mouse studies suggest that a gene screen could include $P A X 6, M A F 1$, $V A X 1, V A X 2$, and $S H H$. For isolated microphthalmia good candidates are CHX10, RX, SOX2, BMP4, BMP7, MAF1, and NOG. Since coloboma and microphthalmia are sometimes seen together, these are not mutually exclusive lists. Candidate gene screens are currently limited, however, because probably most coloboma genes are still not known and gene screening for genetic eye diseases is currently very limited in most countries. The most effective genetic screening is still in those families where a causative mutation has already been established.

Another important principle in this group of patients is that incomplete penetrance and variable expressivity in autosomal dominant cases seems to be the rule rather than the exception. ${ }^{110}$ Clinical variability may be explained by modifier genes, an influence of the allele in trans, sex, mosaicism, or environmental factors. For example, evidence suggests that disease penetrance can be increased by coinheritance of a specific gene defect with a low-expressed wild-type allele. ${ }^{111} 112$ Also data from mouse studies indicate that non-penetrance or a difference in severity for the coloboma phenotype depends on the mouse genetic background. ${ }^{59}$ A1 Although rapid progress has been made in understanding the basis of incomplete penetrance and the differences in expressivity, they still remain unknown for most genetic disorders. Therefore, patients should be counselled assuming there is full penetrance of the gene defect, unless a specific modifying mechanism has been identified.

\section{CONCLUSIONS}

A significant body of information is now emerging on the molecular mechanisms involved in the pathogenesis of ocular coloboma. Although many elements are still missing the skeleton for a classification can now be constructed based on molecular pathogenesis. Coloboma can be classified as a disease of increasing severity, for example as (i) being isolated, (ii) being associated with other ocular anomaly (for example microphthalmos), and (iii) being associated with other CNS anomaly and with systemic manifestations outside the CNS. The first two subsections would incorporate the classification of Hornby and co-workers ${ }^{4}$ where visual prognosis is linked to severity of ocular malformation and also takes into account the CNS and systemic abnormalities so commonly seen with ocular coloboma.

The key to this subclassification, however, is that it can be correlated with groups of coloboma genes, in particular with the timing of their action. Coloboma-related genes such as SHH and SIX3 which act prior to eye development (that is, before 20 days post conception) are associated with severe neurological deficits and systemic anomalies. Other coloboma genes acting later in eye development (after 20 days post conception) are usually associated with either milder CNS and systemic anomalies (for example TCOFI) or isolated coloboma (for example PAX6, MAF1, CHX10, RBP4). Other factors as well as timing of expression are also important. Site of expression is relevant. For example, $S H H$ is ubiquitously expressed and so it is not surprising that mutation leads to multiple anomalies. Other genes, for example $M A F 1$, are thought to be exclusively expressed in the eye and so mutation leads to an isolated eye phenotype. Genetic redundancy is also a factor in the phenotype associated with a particular gene, for example PAX6 and $C H X 10$ are expressed elsewhere in the developing CNS but mutations are mainly associated with eye anomalies, presumably because their function can be compensated for elsewhere in the CNS. Thus, to a limited extent phenotypic characterisation (the CNS and other systemic anomalies as well as the ocular phenotype) can be helpful in identifying the underlying molecular deficit.

\section{ELECTRONIC-DATABASE INFORMATION}

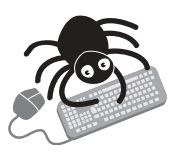

The URLs mentioned in this paper are: Human PAX6 Allelic Variant Database, http://pax6.hgu.mrc.ac.uk/ Tables/tables.htm; and OMIM, www.ncbi.nlm.nih. gov/entrez/query.fcgi? db=OMIM.

\section{Authors' affiliations}

C Y Gregory-Evans, S Halford, K Gregory-Evans, Department of Visual Neuroscience, Faculty of Medicine, Imperial College London, London, UK

C Y Gregory-Evans, M J Williams, Department of Cell and Molecular Biology, Faculty of Medicine, Imperial College London, London, UK 
S Halford, Department of Genomic Medicine, Faculty of Medicine, Imperial College London, London, UK

This work was supported by Birth Defects Foundation (Grant Ref 03/05).

Conflict of interest: none declared.

\section{REFERENCES}

1 Bermejo E, Martinez-Frias ML. Congenital eye malformations: clinicalepidemiological analysis of 1,124,654 consecutive births in Spain. Am J Med Genet 1998;75:497-504

2 Stoll C, Alembik Y, Dott B, Roth MP. Congenital eye malformations in 212,479 consecutive births. Ann Genet 1997:40:122-8.

3 Porges Y, Gershoni-Baruch R, Leibu R, Goldscher D, Zonis S, Shapira I, Miller B. Hereditary microphthalmia with colobomatous cyst. Am J Ophthalmol 1992;114:30-4.

4 Hornby SJ, Adolph S, Gilbert CE, Dandona L, Foster A. Visual acuity in children with coloboma: clinical features and a new phenotypic classification system. Ophthalmology 2000;107:511-20.

5 MacDonald AE. Causes of blindness in Canada: an analysis of 24,605 cases registered with the Canadian National Institute for the Blind. Can Med Assoc J 1965:92:264-79.

6 Fujiki K, Nakajima A, Yasuda N, Tanabe U, Kabaswa K. Genetic analysis of microphthalmos. Ophthalmic Paediatr Genet 1982;1:139-49.

7 Mann I. Developmental abnormalities of the eye. Philadelphia: Lippincott, 1957:81-103.

8 Ozanics V, Jacobiec FA. Prenatal development of the eye and its adnexa. In: Jacobiec FA, ed. Ocular anatomy, embryology and teratology. Philadelphia: Harper and Row, 1982:11-96.

9 Remington LA, McGill EC. Ocular embryology. In: McGill ED, ed. Clinicalanatomy of the visual system. Oxford: Butterworth-Heinemann, 1997:103-21.

10 Onwochei BC, Simon JW, Bateman JB, Couture KC, Mir E. Ocular coloboma. Surv Ophthalmol 2000;45:175-94.

11 Graw J. The genetic and molecular basis of congenital eye defects. Nat Rev Genet 2003:4:876-88.

12 Gregory-Evans K. Developmental disorders of the globe. In: Moore A, Lightman S, eds. Fundamentals of clinical ophthalmology: paediatric ophthalmology. London: BMJ Books, 2000:53-61.

13 Pagon RA. Ocular coloboma. Surv Ophthalmol 1981;25:223-36.

14 Vieira H, Gregory-Evans K, Lim N, Brookes JL, Brueton LA, GregoryEvans CY. First genomic localisation of oculo-oto-dental syndrome with linkage to chromosome 20q13.1. Invest Ophthalmol Vis Sci 2002;43:2540-5.

15 Blackmon DM, Lambert SR. Congenital iris coloboma repair using a modified McCannel suture technique. Am J Ophthalmol 2003;135:730-2.

16 Burk SE, Da Mata AP, Snyder ME, Cionni RJ, Cohen JS, Osher RH. Prosthetic iris implantation for congenital, traumatic, or functional iris deficiencies. J Cataract Refract Surg 2001;27:1732-40.

17 Watt RH. Inferior congenital iris coloboma repair and IOL implantation. $J$ Cataract Refract Surg 1993;19:669-71.

18 Yanoff M, Fine BS. Ocular pathology: a text and atlas. Philadelphia: Harper and Row, 1982:402-4

19 Jesberg DO, Schepens CL. Retinal detachment associated with coloboma of the choroid. Arch Ophthalmol 1961;65:163-73.

20 Daufenbach DR, Ruttum MS, Pulido JS, Keech RV. Chorioretinal colobomas in a pediatric population. Ophthalmology 1998;105:1455-8.

21 Morrison DA, Fleck B. Prevalence of retinal detachment in children with chorioretinal colobomas. Ophthalmology 1999;106:645-6.

22 Gopal L, Badrinath SS, Sharma T, Parikh SN, Shanmugam MS, Bhende PS, Agrawal R, Deshpande DA. Surgical management of retinal detachments related to coloboma of the choroid. Ophthalmology 1998;105:804-9.

23 Unlu N, Kocaoglan H, Acar MA, Aslan BS, Duman S. Surgical management of retinal detachment with choroidal coloboma. Eur J Ophthalmol 2002; 12:299-303.

24 Leff SR, Britton WA, Brown GC, Lucier AC, Brown JF. Retinochoroidal coloboma associated with subretinal neovascularization. Retina 1985:5:154-6.

25 Shaikh S, Trese M. Infantile choroidal neovascularization associated with choroidal coloboma. Retina 2003;23:585-6.

26 Guirgis MF, Lueder GT. Choroidal neovascular membrane associated with optic nerve coloboma in a patient with CHARGE association. Am J Ophthalmol 2003;135:919-20.

27 Dailey JR, Cantore WA, Gardner TW. Peripapillary choroidal neovascular membrane associated with an optic nerve coloboma. Arch Ophthalmol 1993;111:441-2.

28 Gopal L, Badrinath SS, Kumar KS, Doshi G, Biswas N. Optic disc in fundus coloboma. Ophthalmology 1996;103:2120-6.

29 Aroichane M, Traboulsi El. Congenital anomalies of the optic nerve head. In: Traboulsi El, ed. Genetic diseases of the eye. Oxford: Oxford University Press, 1998:115-41.

30 Kindler P. Morning glory syndrome: unusual congenital optic disk anomaly. Am J Ophthalmol 1970;69:376-84.

31 Russell-Eggitt I, Blake K, Taylor D, Wyse R. The eye in CHARGE association. BrJ Ophthalmol 1990;74:421-6.

32 Baker RS, Ross PA, Baumann RJ. Neurologic complications of the epidermal nevus syndrome. Arch Neurol 1987:44:227-32.

33 Hauptman O, Albert DM, Plowman MC, Hopfer SM, Sunderman FW Jr. Ocular malformations of Xenopus laevis exposed to nickel during embryogenesis. Ann Clin Lab Sci 1993;23:397-406.
34 Colson A, Lederer J, Michiels J. Ocular lesions induced by saccharin and its pollutants in the rat fetus. J Fr Ophtalmol 1984;7:399-410.

35 Hampton GR, Krepostman Jl. Ocular manifestations of the fetal hydantoin syndrome. Clin Pediatr (Phila) 1981;20:475-8.

36 Kern $M$, Tatar-Kiss Z, Kertai P, Foldes I. Teratogenic effect of 2'-thiourea in the rat. Acta Morphol Acad Sci Hung 1980;28:259-67.

37 Karnofsky DA, Lacon CR. The effects of 1-beta-D-arabinofuranosylcytosine on the developing chick embryo. Biochem Pharmacol 1966;15:1435-42.

38 Miller MT, Stromland K. Teratogen update-thalidomide: a review, with a focus on ocular findings and new potential uses. Teratology 1999;60:306-21.

39 Stromland K, Pinazo-Duran MD. Ophthalmic involvement in the fetal alcohol syndrome: clinical and animal model studies. Alcohol Alcohol 2002;37:2-8.

40 Apple DJ, Bennett TO. Multiple systemic and ocular malformations associated with maternal LSD usage. Arch Ophthalmol 1974;92:301-3.

41 Sutcliffe AG, Jones RB, Woodruff G. Eye malformations associated with treatment with carbamazepine during pregnancy. Ophthal Genet 1988;19:59-62.

42 Kroes HY, Reefhuis J, Cornel MC. Is there an association between maternal carbamazepine use during pregnancy and eye malformations in the child? Epilepsia 2002;43:929-31.

43 Rahi JS, Sripathi S, Gilbert CE, Foster A. Childhood blindness due to vitamin A deficiency in India: regional variations. Arch Dis Child 1995;72:330-3.

44 Hornby SJ, Ward SJ, Gilbert CE, Dandona L, Foster A, Jones RB. Environmental risk factors in congenital malformations of the eye. Ann Trop Paediatr 2002:22:67-77

45 Hornby SJ, Ward SJ, Gilbert CE. Eye birth defects in humans may be caused by a recessively-inherited genetic predisposition to the effects of maternal vitamin A deficiency during pregnancy. Med Sci Monit 2003;9:23-6.

46 Hittner HM, Desmond MM, Montgomery JR. Optic nerve manifestations of human congenital cytomegalovirus infection. Am J Ophthalmol 1976;81:661-5

47 Suhardjo, Utomo PT, Agni AN. Clinical manifestations of ocular toxoplasmosis in Yogyakarta, Indonesia: a clinical review of 173 cases. Southeast Asian J Trop Med Public Health 2003:34:291-7.

48 Nielson JN, Carlton WW. Colobomatous microphthalmos in a New Zealand white rabbit, arising from a colony with suspected vitamin E deficiency. Lab Anim Sci 1995;45:320-2.

49 Kuno H, Kemi M, Matsumoto H. Critical period for induction of ocular anomalies produced by soft $x$-ray irradiation $(4.6 \mathrm{~Gy})$ in the rat $\mathrm{Fl}$ offspring. Jikken Dobutsu 1994:43:115-9.

50 Cekan E, Slanina P, Bergman K, Tribukait B. Effects of dietary supplementation with selenomethionine on the teratogenic effect of ionizing radiation in mice. Acta Radiol Oncol 1985:24:459-63.

51 Edwards MJ. Hyperthermia as a teratogen: a review of experimental studies and their clinical significance. Teratog Carcinog Mutag 1986;6:563-82.

52 Nilsen NO. Eye malformations in chick embryos exposed to elevated incubation temperatures. Acta Ophthalmol (Copenh) 1968:46:322-8.

53 Jean D, Ewan K, Gruss P. Molecular regulators involved in vertebrate eye development. Mech Dev 1998;76:3-18.

54 Schrem H, Klempnauer J, Borlak J. Liver-enriched transcription factors in liver function and development. Part I: The hepatocyte nuclear factor network and liver-specific gene expression. Pharmacol Rev 2002;54:129-58.

55 Robles Al, Linke SP, Harris CC. The p53 network in lung carcinogenesis. Oncogene 2002;21:6898-907.

56 Cohen MM. The Hedgehog signalling network. Am J Med Genet 2003;123A:5-28

57 Schimmenti LA, de la Cruz J, Lewis RA, Karkera JD, Manligas GS, Roessler E, Muenke M. Novel mutation in Sonic hedgehog in non-syndromic colobomatous microphthalmia. Am J Med Genet 2003;116A:215-21.

58 Eccles MR, Schimmenti LA. Renal-coloboma syndrome: a multi-system developmental disorder caused by PAX2 mutations. Clin Genet 1999;56:1-9.

59 Torres M, Gómez-Pardo E, Gruss P. Pax 2 contributes to inner ear patterning and optic nerve trajectory. Development 1996:122:3381-91.

60 Hallonet M, Hollemann T, Pieler T, Gruss P. Vax1, a novel homeoboxcontaining gene, directs development of the basal forebrain and visual system. Genes Dev 1999;13:3106-44.

61 Barbieri AM, Broccoli V, Bovolenta P, Alfano G, Marchitiello A, Crippa L, Bulfone A, Marigo V, Ballabio A. Vax2 inactivation in mouse determines alteration of the eye dorsal-ventral axis, misrouting of the optic fibres and eye coloboma. Development 2002;129:805-13.

62 Huh S, Hatini V, Marcus RC, Li SC, Lai E. Dorsal-ventral patterning defects in the eye of BF-1-deficient mice associated with a restricted loss of shh expression. Dev Biol 1999;211:53-63.

63 Means AL, Gudas $\mathrm{L}$. The roles of retinoids in vertebrate development. Annu Rev Biochem 1995;64:202-33.

64 Wilson JG, Roth CB, Warkany J. An analysis of the syndrome of malformations induced by maternal vitamin A deficiency: effects of restoration of vitamin $\mathrm{A}$ at various times during gestation. Am J Anat 1953;92:189-217

65 Seeliger MW, Biesalski HK, Wissinger B, Gollnick H, Gielen S, Frank J, Beck S, Zrenner E. Phenotype in retinol deficiency due to hereditary defect in retinol binding protein synthesis. Invest Ophthalmol Vis Sci 1999;40:3-11.

66 Helms JA, Kim CH, Hu D, Minkoff R, Thaller C, Eichele G. Sonic hedgehog participates in craniofacial morphogenesis and is down-regulated by teratogenic doses of retinoic acid. Dev Biol 1997; 187:25-35.

67 Stull DL, Wikler KC. Retinoid-dependent gene expression regulates early morphological events in the development of the murine retina. J Comp Neurol 200;417:289-98. 
68 Hahn H, Wicking C, Zaphiropoulos PG, Gailani MR, Shanley S, Chidambaram A, Vorechovsky I, Holmberg E, Unden AB, Gillies S, Negus K, Smyth I, Pressman C, Leffell DJ, Gerrard B, Goldstein AM, Dean M, Toffgard R, Chenevix-Trench G, Wainwright B, Bale AE. Mutations of the human homolog of Drosophila patched in the nevoid basal cell carcinoma syndrome. Cell 1996;85:841-51.

69 Sasagawa S, Takabatake T, Takabatake Y, Muramatsu T, Takeshima K. Axes establishment during eye morphogenesis in Xenopus by coordinate and antagonistic actions of BMP4, Shh and RA. Genesis 2002;33:86-96.

70 Sabapathy K, Jochum W, Hochedlinger K, Chang L, Karin M, Wagner EF. Defective neural tube morphogenesis and altered apoptosis in the absence of both JNK1 and JNK2. Mech Dev 1999;89:115-24.

71 Weston CR, Wong A, Hall JP, Goad ME, Flavell RA, Davis RJ. JNK initiates a cytokine cascade that causes Pax2 expression and closure of the optic fissure. Genes Dev 2003;17:1271-80.

72 Ton CC, Hirvonen H, Miwa H, Weil MM, Monaghan P, Jordan T, van Heyningen V, Hastie ND, Meijers-Heijboer H, Drechsler M. Positional cloning and characterisation of a paired box and homeobox-containing gene for the aniridia region. Cell 1991;67:1059-74.

73 Hanson IM. PAX6 and congenital eye malformations. Paediatr Res 2003;54:791-6.

74 Azuma N, Yamaguchi Y, Handa H, Tadokora K, Asaka A, Kawase E, Yamada M. Mutations of the PAX6 gene detected in patients with a variety of optic-nerve malformations. Am J Hum Genet 2003;72:1565-70.

75 Baulmann DC, Ohlmann A, Flügel-Koch C, Goswami S, Cvekl A, Tamm ER. Pax6 heterozygous eyes show defects in chamber angle differentiation that are associated with a wide spectrum of other anterior eye segment abnormalities. Mech Dev 2002;1 18:3-17.

76 Ferda-Percin E, Ploder LA, Yu JJ, Arici K, Horsford DJ, Rutherford A, Bapat B, Cox DW, Duncan AM, Kalnins VI, Kocak-Altintas A, Sowden JC, Traboulsi E, Sarafarzi M. Mclnnes RR. Human microphthalmia associated with mutations in the retinal homeobox gene CHX10. Nat Genet 2000;25:397-401.

77 Green ES, Stubbs JL, Levine EM. Genetic rescue of cell number in a mouse model of microphthalmia: interactions between $\mathrm{Ch} \times 10$ and G1-phase cell cycle regulators. Development 2003;130:539-52.

78 Jamieson RV, Perveen R, Kerr B, Carette M, Yardley J, Heon E, Wirth MG van Heyningen V, Donnai D, Munier F, Black GC. Domain disruption and mutation of the bZIP transcription factor, MAF, associated with cataract, ocular anterior segment dysgenesis and coloboma. Hum Mol Genet 2002;11:33-42

79 Sakai M, Serria MS, Ikeda H, Yoshida K, Imaki J, Nishi S. Regulation of c maf gene expression by Pax6 in cultured cells. Nucleic Acids Res 2001;29:1228-37.

80 Shimada N, Aya-Murata T, Reza HM, Yasuda K. Cooperative action between L-Maf and Sox2 on delta-crystallin gene expression during chick lens development. Mech Dev 2003;120:455-65.

81 Wallis DE, Roessler E, Hehr U, Nanni L, Wiltshire T, Richieri-Costa A, Gillessen-Kaesbach G, Zackai EH, Rommens J, Muenke M. Mutations in the homeodomain of the human SIX3 gene cause holoprosencephaly. Nat Genet 1999;22:196-8.

82 Lagutin OV, Zhu CC, Kobayashi D, Topczewski J, Shimamura K, Puelles L, Russell HR, McKinnon PJ, Solnica-Krezel L, Oliver G. Six3 repression of Wnt signaling in the anterior neuroectoderm is essential for vertebrate forebrain development. Genes Dev 2003;17:368-79.

83 Wargelius A, Seo HC, Austbo L, Fiose A. Retinal expression of zebrafish six3.1 and its regulation by Pax6. Biochem Biophys Res Commun 2003:309:475-81.

84 Zuber ME, Gestri G, Viczian AS, Barsacchi G, Harris WA. Specification of the vertebrate eye by a network of eye field transcription factors. Development 2003;130:5155-67.

85 Macdonald R, Barth KA, Xu Q, Holder N, Mikkola I, Wilson SW. Midline signalling is required for Pax gene regulation and patterning of the eyes. Development 1995; 121:3267-78.

86 Zhang L, Mathers PH, Jamrich M. Function of Rx, but not Pax6, is essential for the formation of retinal progenitor cells in mice. Genesis 2000;28:135-42.

87 Dudley AT, Lyons KM, Robertson EJ. A requirement for bone morphogenetic protein-7 during development of the mammalian kidney and eye. Genes Dev 1995:9:2795-807.

88 Wawersik S, Purcell P, Rauchman M, Dudley AT, Robertson EJ, Maas R. BMP7 acts in murine lens placode development. Dev Biol 1999;207:176-88.

89 Voronina VA, Kozhemyakina EA, O'Kernick CM, Kahn ND, Wenger SL, Linberg JC, Schneider AS, Mathers PH. Mutations in the human RAX homeobox gene in a patient with anophthalmia and sclerocornea. Hum Mol Genet 2004;13:315-22.

90 Adler R, Belecky-Adams TL. The role of bone morphogenetic proteins in the differentiation of the ventral optic cup. Development 2002;129:3161-71.

91 Solursh M, Langille RM, Wood J, Sampath TK. Osteogenic protein-1 is required for mammalian eye development. Biochem Biophys Res Commun 1996;218:438-43

92 Wordinger RJ, Agarwal R, Talati M, Fuller J, Lambert W, Clark AF. Expression of bone morphogenetic proteins (BMP), BMP receptors, and BMP associated proteins in human trabecular meshwork and optic nerve head cells and tissues. Mol Vis 2002;8:241-50.

93 Jena N, Martin-Seisdedos C, McCue P, Croce CM. BMP7 null mutation in mice: developmental defects in skeleton, kidney, and eye. Exp Cell Res 1997:230:28-37.

94 Dunn NR, Winnier GE, Hargett LK, Schrick JJ, Fogo AB, Hogan BL. Haploinsufficient phenotypes in Bmp4 heterozygous null mice and modification by mutations in Gli3 and Alx4. Dev Biol 1997;188:235-47.
95 Dudley AT, Robertson EJ. Overlapping expression domains of bone morphogenetic protein family members potentially account for limited tissue defects in BMP7 deficient embryos. Dev Dyn 1997;208:349-62.

96 Groppe J, Greenwald J, Wiater E, Rodriguez-Leon J, Economides AN, Kwaitkowski W, Affolter M, Vale WW, Belmonte JC, Choe S. Structural basis of BMP signalling inhibition by the cystine knot protein Noggin. Nature 2002;420:636-42

97 Sharov AA, Weiner L, Sharova TY, Siebenhaar F, Atoyan R, Reginato AM, McNamara CA, Funa K, Gilchrest BA, Brissette JL, Botchkarev VA. Noggin overexpression inhibits eyelid opening by altering epidermal apoptosis and differentiation. EMBO J 2003;22:2992-3003.

98 Bachiller D, Klingensmith J, Kemp C, Belo JA, Anderson RM, May SR, McMahon JA, McMahon AP, Harland RM, Rossant J, De Robertis EM. The organizer factors Chordin and Noggin are required for mouse forebrain development. Nature 2000;403:658-61

99 You L, Kruse FE. Differential effect of activin A and BMP-7 on myofibroblast differentiation and the role of the Smad signaling pathway. Invest Ophthamol Vis Sci 2002;43:72-81

100 Van de Putte T, Maruhashi M, Francis A, Nelles M, Kondoh $\mathrm{H}$ Huylebroeck D, Higashi Y. Mice lacking Zfh $x 1 b$, the gene that codes for Smad-interacting protein-1, reveal a role for multiple neural crest cell defects in the etiology of Hirschsprung disease-mental retardation syndrome. Am J Hum Genet 2003:72:465-70.

101 Mowat DR, Wilson MJ, Goossens M. Mowat-Wilson syndrome. J Med Genet 2003;40:305-10.

102 Gregory-Evans CY, Vieira H, Dalton R, Adams GG, Salt A, GregoryEvans $K$. Ocular coloboma and high myopia with Hirschsprung disease associated with a novel ZFHX1B missense mutation and trisomy 21. Am JMed Genet 2004 (in press)

103 Fantes J, Ragge NK, Lynch SA, McGill NI, Collin JR, Howard-Peebles PN, Hayward C, Vivian AJ, Williamson K, van Heyningen V, FitzPatrick DR. Mutations in SOX2 cause anophthalmia. Nat Genet 2003;33:461-2.

104 Dollfus H, Biswas P, Kumaramanickavel G, Stoetzel C, Quillet R, Biswas J, Lajeunie E, Renier D, Perrin-Schmitt F. Saethre-Chotzen syndrome: notable intrafamilial phenotypic variability in a large family with Q28X TWIST mutation. Am J Med Genet 2002;109:218-25.

105 Espinosa-Parrilla Y, Amile J, Augé J, Encha-Razavi F, Munnich A, Lyonnet S, Vekemans M, Attie-Bitach T. Expression of the SMADIP1 gene during human development. Mech Dev 2002;114:187-91.

106 Verschueren K, Remacle JE, Collart C, Kraft H, Baker BS, Tylzanowski P, Nelles L, Wuytens G, Su MT, Bodmer R, Smith JC, Huylebroeck D. SIP1, a novel zinc finger/homeodomain repressor, interacts with Smad proteins and binds to $5^{\prime}$-CACCT sequences in candidate target genes. J Biol Chem 1999;274:20489-98.

107 Eisaki A, Kuroda H, Fukui A, Asashima M. XSIPI, a member of two-handed zinc finger proteins, induced anterior neural markers in Xenopus laevis animal cap. Biochem Biophys Res Commun 2000;271:151-7.

108 Li YX, Farrell MJ, Liu R, Mohanty M, Kirby ML. Double-stranded RNA injection produces null phenotypes in zebrafish. Dev Biol 2000;217:394-405

109 Morrison D, FitzPatrick D, Hanson I, Williamson K, van Heyningen V, Fleck B, Jones I, Chalmers J, Campbell H. National study of microphthalmia, anophthalmia, and coloboma (MAC) in Scotland: investigation of genetic aetiology. J Med Genet 2002;39:16-22.

110 Morle L, Bozon M, Zech JC Alloisio N, Raas-Rothchild A, Philippe C, Lambert JC, Godet J, Plauchu H, Edery P. A locus for autosomal dominant colobomatous microphthalmia maps to chromosome 15q12-q15. Am J Hum Genet 2000;67:1592-7.

111 Gouya L, Puy H, Robreau AM, Lyoumi S, Lamoril J, Da Silva V, Grandchamp B, Deybach JC. Modulation of penetrance by the wild-type allele in dominantly inherited erythropoietic protoporphyria and acute hepatic porphyrias. Hum Genet 2004;1 14:256-62.

112 Vithana EN, Abu-Afieh L, Pelsini L, Winchester E, Hornan D, Bird AC Hunt DM, Bustin SA, Bhattacharya SS. Expression of PRPF31 mRNA in patients with autosomal dominant retinitis pigmentosa: a molecular clue for incomplete penetrance? Invest Ophthalmol Vis Sci 2003;44:4204-9.

113 van Gennip AH, Abeling NGGM, Stroomer AEM, van Lenthe H, Bakker HD. Clinical and biochemical findings in six patients with pyrimidine degradation defects. J Inherit Metab Dis 1994;17:130-2.

114 Hurst JA, Markiewicz M, Kumar D, Brett EM. Unknown syndrome: Hirschsprung's disease, microcephaly, and iris coloboma: a new syndrome of defective neuronal migration. J Med Genet 1988;25:494-7.

115 Korner C, Knauer R, Stephani U, Marquardt T, Lehle L, von Figura K. Carbohydrate deficient glycoprotein syndrome type IV: deficiency of dolichyl-P-Man:Man(5)GlcNAc(2)-PP-dolichyl mannosyltransferase. EMBO J 1999; 18:6816-22.

116 Ozeki H, Shirai S, lkeda K, Ogura Y. Anomalies associated with AxenfeldRieger syndrome. Graefes Arch Clin Exp Ophthalmol 1999;237:730-4.

117 Bard LA. Congenital contractural arachnodactyly and intraocular colobomas. Birth Defects Orig Artic Ser 1979;15:189-205.

118 Treacher Collins Syndrome Collaborative Group. Positional cloning of a gene involved in the pathogenesis of Treacher Collins syndrome. Nat Genet 1996; 12:130-6

119 Beltran-Valero de Bernabe D, Currier S, Steinbrecher A, Celli J, van Beusekom E, van der Zwaag B, Kayserili H, Merlini L, Chitayat D Dobyns WB, Cormand B, Lehesjoki AE, Cruces J, Voit T, Walsh CA, van Bokhoven $\mathrm{H}$, Brunner HG. Mutations in the O-mannosyltransferase gene POMT1 give rise to the severe neuronal migration disorder Walker-Warburg syndrome. Am J Hum Genet 2002;71:1033-43.

120 Saar K, Al-Gazali L, Sztriha L, Rueschendorf F, Nur-E-Kamal M, Reis A, Bayoumi R. Homozygosity mapping in families with Joubert syndrome 
identifies a locus on chromosome $9 \mathrm{q} 34.3$ and evidence for genetic heterogeneity. Am J Hum Genet 1999;65:1666-71.

121 Keeler LC, Marsh SE, Leeflang EP, Woods CG, Sztriha L, Al-Gazali L, Gururaj A, Gleeson JG. Linkage analysis in families with Joubert syndrome plus oculo-renal involvement identifies the CORS2 locus on chromosome 11p12-q13.3. Am J Hum Genet 2003;73:656-62.

122 Carvalho DR, Alves WV, Minare-Junior A, Peres LC, Pina-Neta JM, Ramos ES. Noonan syndrome associated with unilateral iris coloboma and congenital chylothorax in an infant. Clin Dysmorphol 2003;12:143-4.

123 Guion-Almeida ML, Richieri-Costa A. Callosal agenesis, iris coloboma, and megacolon in a Brazilian boy with Rubinstein-Taybi syndrome. Am J Med Genet 1992;43:929-31.

124 MacRae DW, Howard RO, Albert DM, Hsai YE. Ocular manifestations of the Meckel syndrome. Arch Ophthalmol 1972:88:106-13.

125 Gorski JL. Father-to-daughter transmission of focal dermal hypoplasia associated with nonrandom X-inactivation: support for X-linked inheritance and paternal X chromosome mosaicism. Am J Med Genet 1991;40:332-7.

126 Ropers HH, Zuffardi O, Bianchi E, Tiepolo L. Agenesis of corpus callosum, ocular, and skeletal anomalies (X-linked dominant Aicardi's syndrome) in a girl with balanced X/3 translocation. Hum Genet 1982;61:364-8.

127 Graham JM, Wheeler P, Tackels-Horne D, Lin AE, Hall BD, May M, Short KM, Schwartz CE, Cox TC. A new X-linked syndrome with agenesis of the corpus callosum, mental retardation, coloboma, micrognathia, and a mutation in the alpha 4 gene at Xq13. Am J Med Genet 2003;123A:37-44.

$128 \mathrm{Ng}$ D, Thakker N, Corcoran CM, Donnai D, Perveen R, Schneider A, Hadley DW, Tiff'C, Zhang L, Wiklie AO, van der Smagt JJ, Gorlin RJ, Burgess SM, Bardwell VJ, Black GC, Biesecker LG. Oculofaciocardiodental and Lenz microphthalmia syndromes result from distinct classes of mutations in BCOR. Nat Genet 2004;36:411-6.

129 Robertson SP, Twigg SRF, Sutherland-Smith AJ, Biancalana V, Gorlin RJ, Horn D, Kenwrick SJ, Kim CA, Morava E, Newbury-Ecob R, Orstavik KH, Quarrell OW, Schwartz CE, Shears DJ, Suri M, Kendrick-Jones J, Wilkie AO, OPD-spectrum Disorders Clinical Collaborative Group. Localized mutations in the gene encoding the cytoskeletal protein filamin $A$ cause diverse malformations in humans. Nat Genet 2003;33:487-91.

130 Stratton RF, Bluestone DL. Oto-palatal-digital syndrome type II with X-linked cerebellar hypoplasia/hydrocephalus. Am J Med Genet 1991:41:169-72.

131 Arias S, Rolo M, Gonzalez N. Terminal deletion of the short arm of chromosome 2, informative for acid phosphatase (ACP1), malate dehydrogenase (MDH1), and coloboma of iris loci. Cytogenet Cell Genet 1984:37:401A.

132 Pallotta R. Iris coloboma, ptosis, hypertelorism, and mental retardation: a new syndrome possibly localised on chromosome 2. J Med Genet 1991;28:342-4

133 Nixon J, Oldridge $M$, Wilkie $A O$, Smith $K$. Interstitial deletion of $2 q$ associated with craniosynostosis, ocular coloboma, and limb abnormalities: cytogenetic and molecular investigation. Am J Med Genet 1997:70:324-7.

134 Zollino M, Lecce R, Fischetto R, Murdolo M, Faravelli F, Selicorni A, Butte C, Memo L, Capovilla G, Neri G. Mapping the Wolf-Hirschhorn syndrome phenotype outside the currently accepted WHS critical region and defining a new critical region, WHSCR-2. Am J Hum Genet 2003:72:590-7.

135 Motegi T, Nakamura K, Terakawa T, Oohira A, Minoda K, Kishi K, Yanagawa Y, Hayakawa H. Deletion of a single chromosome band $4 q 26$ in a malformed girl: exclusion of Rieger syndrome associated gene(s) from the 4q26 segment. J Med Genet 1998;25:628-33.

136 Taysi K, Burde RM, Rohrbaugh JR. Terminal long arm deletion of chromosome 7 and retino-choroidal coloboma. Ann Genet 1982;25:159-61.

137 Pivnick EK, Velagaleti GVN, Wilroy RS, Smith ME, Rose SR, Tipton RE, Tharapel AT. Jacobsen syndrome: report of a patient with severe eye anomalies, growth hormone deficiency, and hypothyroidism associated with deletion 11 (q23q25) and review of 52 cases. J Med Genet 1996;33:772-8.

138 Vissers LE, van Ravenswajii CM, Admiraal R, Hurst JA, de Vries BB, Janssen IM, der Vliet WA, Huys EH, de Jong PJ, Hamel BCJ, Schoenmakers EF, Brunner HG, Veltman JA, van Kessel AG. Mutations in a new member of the chromodomain family cause CHARGE syndrome. Nat Genet 2004;36:955-7.

139 Werner W, Kraft S, Callen DF, Bartsch O, Hinkel GK. Small deletion of $16 \mathrm{q} 23.1 \rightarrow 16 \mathrm{q} 24.2$ [del(16)(q23.1q24.2).ish del(16)(q23.1q24.2)(D16S395+, D16S348-, P5432+)] in a boy with iris coloboma and minor anomalies. Am J Med Genet 1997;70:371-6.

140 McTaggart KE, Budarf ML, Driscoll DA, Emanuel BS, Ferreira P, McDermid HE. Cat eye syndrome chromosome breakpoint clustering: identification of two intervals also associated with $22 \mathrm{q} 11$ deletion syndrome breakpoints. Cytogenet Cell Genet 1998;81:222-8.

141 Morrison DA, FitzPatrick DR, Fleck BW. Iris coloboma and a microdeletion of chromosome 22: del(22)(q1 1.22). Br J Ophthalmol 2002;86:1316.

142 Bartholomew DW, Jabs EW, Levin LS, Ribovich R. Single maxillary central incisor and coloboma in hypomelanosis of lto. Clin Genet 1987:32:370-3.

143 Nothen MM, Knopfle G, Fodisch HJ, Zerres K. Steinfeld syndrome: report of a second family and further delineation of a rare autosomal dominant disorder. Am J Med Genet 1993;46:467-70.

144 Toker E, Elcioglu N, Ozcan E, Yenice O, Ogut M. Colobomatous macrophthalmia with microcornea syndrome: report of a new pedigree. Am J Med Genet 2003;121A:25-30.

145 Ravine D, Ragge NK, Stephens D, Oldridge M, Wilkie AO. Dominant coloboma-microphthalmos syndrome associated with sensorineural hearing loss, hematuria and cleft lip/palate. Am J Hum Genet 1997;72:227-36.

146 Aalfs CM, van Schooneveld MJ, van Keulen EM, Hennekam RC. Further delineation of the acro-renal-ocular syndrome. Am J Med Genet 1996;62:276-81.
147 Richardson E, Davison C, Moore A. Colobomatous microphthalmia with midfacial cleffing: part of the spectrum of branchio-oculo-facial syndrome? Ophthal Genet 1996;17:59-65.

148 Shashi V, Zunich J, Kelly TE, Fryburg JS. Neuroectodermal (CHIME) syndrome: an additional case with long term follow up of all reported cases. J Med Genet 1995;32:465-9.

149 Morrison DA, FitzPatrick DR, Fleck BW. Iris coloboma with iris heterochromia: a common association. Arch Ophthal 2000;118:1590-1

150 Ming JE, Russell KL, Bason L, McDonald-McGinn DM, Zackai EH. Coloboma and other ophthalmologic anomalies in Kabuki syndrome: distinction from charge association. Am J Med Genet 2003;123A:249-52.

151 Moretti-Ferreira D, Koiffmann CP, Listik M, Setian N, Waintal A. Macrosomia, obesity, macrocephaly and ocular abnormalities (MOMO syndrome) in two unrelated patients: delineation of a newly recognized overgrowth syndrome. Am J Med Genet 1993;46:555-8.

152 Rudnik-Schoneborn S, Zerres K. A further patient with Pai syndrome with autosomal dominant inheritance? J Med Genet 1994:31:497-8.

153 Temple IK, Eccles DM, Winter RM, Baraitser M, Carr SB, Shortland D, Jones MC, Curry C. Craniofacial abnormalities, agenesis of the corpus callosum, polysyndactyly and abnormal skin and gut development-the Curry Jones syndrome. Clin Dysmorphol 1995:4:116-29.

154 Verloes A, Temple IK, Bonnet S, Bottani A. Coloboma, mental retardation, hypogonadism, and obesity: critical review of the so-called Biemond syndrome type 2, updated nosology, and delineation of three 'new' syndromes. Am J Med Genet 1997:69:370-9.

155 Bondurand N, Kuhlbrodt K, Pingault V, Enderich J, Sajus M, Tommerup N, Warburg M, Hennekam RC, Read AP, Wegner M, Goossens M. A molecular analysis of the Yemenite deaf-blind hypopigmentation syndrome: SOX10 dysfunction causes different neurocristopathies. Hum Mol Genet 1999:8:1785-9.

156 Tsukahara M, Opitz JM. Dubowitz syndrome: review of 141 cases including 36 previously unreported patients. Am J Med Genet 1996;63:277-89.

157 Temtamy SA, Salam MA, Aboul-Ezz EHA, Hussein HA, Helmy SA Shalash BA. New autosomal recessive multiple congenital abnormalities/ mental retardation syndrome with craniofacial dysmorphism, absent corpus callosum, iris colobomas and connective tissue dysplasia. Clin Dysmorphol 1996;5:231-40

158 Pagon RA, Kalina RE, Lechner DJ. Possible autosomal-recessive ocular coloboma. Am J Med Genet 1981:9:189-93.

159 Gollop TR, Kiota MM, Martins RM, Lucchesi EA, Alvarenga Filho E. Frontofacionasal dysplasia: evidence for autosomal recessive inheritance. Am J Med Genet 1984;19:301-5.

160 Leonardi ML, Pai GS, Wilkes B, Lebel RR. Ritscher-Schinzel cranio-cerebellocardiac (3C) syndrome: report of four new cases and review. Am J Med Genet 2001;102:237-42.

161 Porges Y, Gershoni-Baruch R, Leibu R, Goldscher D, Zonis S, Shapira I, Miller B. Hereditary microphthalmia with colobomatous cyst. Am J Ophthalmol 1992;114:30-4.

162 Avunduk AM, Aslan Y, Kapicioglu Z, Elmas R. High myopia, hypertelorism, iris coloboma, exomphalos, absent corpus callosum, and sensorineural deafness: report of a case and further evidence for autosomal recessive inheritance. Acta Ophthalmol Scand 2000;78:221-2.

163 Verloes A, Lambotte C. Further delineation of a syndrome of cerebellar vermis hypoaplasia, oligophrenia, congenital ataxia, coloboma, and hepatic fibrosis. Am J Med Genet 1989:32:227-32.

164 Ward JR, Saad de Owens C, Sierra IA. Upper limb defects associated with developmental delay, unilateral poorly developed antihelix, hearing deficit, and bilateral choroidal coloboma: a new syndrome. I Med Genet 1992;29:589-91.

165 Jung C, Wolff G, Back E, Stahl M. Two unrelated children with developmental delay, short stature and anterior chamber cleavage disorder, cerebellar hypoplasia, endocrine disturbances and tracheostenosis: a new entity? Clin Dysmorphol 1995;4:44-51.

166 Kapur S, Toriello HV. Apparently new MCA/MR syndrome in sibs with cleft lip and palate and other facial, eye, heart, and intestinal anomalies. Am J Med Genet 1991;41:423-5.

167 Toriello HV, Higgins JV, Miller T. Provisionally unique autosomal recessive chondrodysplasia punctata syndrome. Am J Med Genef 1993:47:797-9.

168 Gurrieri F, Sammito V, Ricci B, lossa M, Bellussi A, Neri G. Possible new type of oral-facial-digital syndrome with retinal abnormalities: OFDS type (VIII). Am J Med Genet 1992;42:789-92.

169 Wilson GN, King TE, Brookshire GS. Index finger hyperphalangy and multiple anomalies: Catel-Manzke syndrome? Am J Med Genet 1993;46:176-9.

170 de Die-Smulders C, Van Schrojenstein Lantman-de Valk H, Fryns JP. Confirmation of a new MR/male pseudohermaphroditism syndrome, Verloes type. Genet Couns 1994:5:73-5.

171 Cohen MM Jr. Hallermann-Streiff syndrome: a review. Am J Med Genet 1991; 41:488-99.

172 Temple IK, Brunner $\mathrm{H}$, Jones B, Burn J, Baraitser M. Midline facial defects with ocular colobomata. Am J Med Genet 1990;37:23-7.

173 Neumann LM, Scheer I, Kunze J, Stover B. Cerebral manifestations, hemihypertrophy and lymphoedema of one leg in a child with epidermal nevus syndrome (Schimmelpenning-Feverstein-Mims). Pediatr Radiol 2003:33:637-40

174 Dodge NN, Dobyns WB. Agenesis of the corpus callosum and DandyWalker malformation associated with hemimegalencephaly in the sebaceous nevus syndrome. Am J Med Genet 1995;56:147-50. 
175 Levin DL, Muster AJ, Newfeld EA, Paul MH. Concordant aortic arch anomalies in monozygotic twins. J Pediatr 1973;83:459-61.

176 Barros-Nunez P, Medina C, Mendoza R, Sanchez-Corona J, Garcia-Cruz D. Unexpected familial recurrence of iris coloboma. A delayed mutation mechanism? Clin Genet 1995:48:160-1.

177 Favor J, Sandulache R, Neuhäuser-Klaus A, Pretsch W, Chatterjee B, Senft E, Wurst B, Blanquet V, Grimes P, Sporle R, Schughart K. The mouse Pax $2^{1 \mathrm{~N}}$ mutation is identical to a human PAX2 mutation in a family with renalcoloboma syndrome and results in developmental defects of the brain, ear, eye and kidney. Proc Natl Acad Sci U S A 1996:93:13870-5.

178 Keller SA, Jones JM, Boyle A, Barrow LL, Killen PD, Green DG, Kapousta NV Hitchcock PF, Swank RT, Meisler MH. Kidney and retinal defects (Krd), a transgene-induced mutation with a deletion of mouse chromosome 19 that includes the Pax2 locus. Genomics 1994;23:309-20.

179 Gage PJ, Suh H, Camper SA. Dosage requirement of Pitx 2 for development of multiple organs. Development 1999;126:4643-51.

180 Singh S, Mishra R, Arango NA, Deng JM, Behringer RR, Saunders GF. Iris hypoplasia in mice that lack the alternatively spliced Pax6(5a) isoform. Proc Natl Acad Sci U S A 2002;99:6812-5.

181 Wilson MC. Coloboma mouse mutant as an animal model of hyperkinesis and attention deficit hyperactivity disorder. Neurosci Biobehav Rev 2000;24:51-7.
182 Xue $Y$, Gao X, Lindsell CE, Norton CR, Chang B, Hicks C, GendronMaguire M, Rand EB, Weinmaster G, Gridley T. Embryonic lethality and vascular defects in mice lacking the Notch ligand Jagged1. Hum Mol Genet 1999:8:723-30

183 West-Mays JA, Zhang J, Nottoli T, Hagopian-Donaldson S, Libby D, Strissel KJ, Williams T. AP-2 alpha transcription factor is required for early morphogenesis of the lens vesicle. Dev Biol 1999;206:46-62.

184 Hawes NL, Smith RS, Chang B, Davisson M, Heckenlively JR, John SW. Mouse fundus photography and angiography: a catalogue of normal and mouse phenotypes. Mol Vis 1999;5:22.

185 Barnett KC. Collie eye anomaly (CEA). J Small Anim Pract 1979;20:537-42.

186 Wyse JP, Hollenberg MJ. Complicated colobomatous microphthalmos in the BW rat: a new form of inherited retinal degeneration. Am J Anat 1977; 149:377-411.

187 Falco M, Barnett KC. The inheritance of ocular colobomata in Charolais cattle. Vet Rec 1978;102:102-4.

188 Barnett KC, Lewis JC. Multiple ocular colobomas in the snow leopard (Uncia uncia). Vet Ophthalmol 2002;5:197-9.

189 Belhorn RW, Barnett KC, Henkind P. Ocular colobomas in domestic cats. J Am Vet Med Assoc 1971;159:1015-21.

190 Abbott UK, Craig RM, Bennett EB. Sex-linked coloboma in the chicken. J Hered 1970;61:95-105. 